University of Nebraska - Lincoln

DigitalCommons@University of Nebraska - Lincoln

Biological Systems Engineering: Papers and

Publications

Biological Systems Engineering

$1-1997$

\title{
Nutrient, Carbon, and Mass Loss During Composting of Beef \\ Cattle Feedlot Manure
}

\author{
Bahman Eghball \\ University of Nebraska-Lincoln \\ James F. Power \\ United States Department of Agriculture \\ John E. Gilley \\ University of Nebraska-Lincoln, john.gilley@ars.usda.gov \\ John W. Doran \\ United States Department of Agriculture
}

Follow this and additional works at: https://digitalcommons.unl.edu/biosysengfacpub

Part of the Biological Engineering Commons

Eghball, Bahman; Power, James F.; Gilley, John E.; and Doran, John W., "Nutrient, Carbon, and Mass Loss During Composting of Beef Cattle Feedlot Manure" (1997). Biological Systems Engineering: Papers and Publications. 130.

https://digitalcommons.unl.edu/biosysengfacpub/130

This Article is brought to you for free and open access by the Biological Systems Engineering at DigitalCommons@University of Nebraska - Lincoln. It has been accepted for inclusion in Biological Systems Engineering: Papers and Publications by an authorized administrator of DigitalCommons@University of Nebraska Lincoln. 


\title{
Waste Management
}

\section{Nutrient, Carbon, and Mass Loss during Composting of Beef Cattle Feedlot Manure}

\author{
Bahman Eghball,* James F. Power, John E. Gilley, and John W. Doran
}

\begin{abstract}
Quantification of nutrient and mass loss during composting is needed to understand the composting process, to implement methods for nutrient conservation, and to reduce potential adverse environmental impact. Beef cattle feedlot manure was composted in a windrow on an open concrete area in 1992, 1993, and 1994 to determine the amounts of nutrient, $C$, and mass loss during composting. The area was enclosed on all sides with a $0.2 \mathrm{~m}$ high metal sheet to direct runoff to a fiberglass tank $(4000 \mathrm{~L})$ during rainfall. Nutrients in runoff represented combined runoff and leaching losses. Nutrients, $C$, and mass loss during composting was determined by the difference between the amounts at the beginning and at the end of the composting. Nitrogen loss during composting ranged from 19 to $42 \%$ and was related to the initial manure $\mathbf{N}$ content. Ammonia volatilization (calculated by difference) accounted for $>92 \%$ of the $\mathrm{N}$ loss whereas combined runoff nitrate and ammonium loss was $<0.5 \%$. Mass loss was relatively low $(15-20 \%)$ while $C$ loss ranged from 46 to $62 \%$ and was basically all through bio-oxidation. Phosphorus runoff loss, the main mechanism for $P$ loss, was low ( $<2 \%$ ). Manure $N / P$ ratio decreased during composting, indicating a greater soil $P$ buildup potential with compost application. Potassium and $\mathrm{Na}$ losses in runoff were high $(>6.5 \%$ each) in 1992 and 1993; they were low ( $<2 \%$ each) in 1994 due to fewer rainfall. Calcium and $\mathrm{Mg}$ losses were $<6 \%$ each year. Nutrient and salt loss during composting resulted in reduced electrical conductivity of the composted manure. Ammonium and $P$ concentrations in runoff would create surface water pollution if runoff was not diluted with fresh water.
\end{abstract}

\begin{abstract}
$A$ Bout 11 million head of cattle and calves are on feed $\mathbf{A}_{\text {at }}$ any time in the USA (USDA, 1993). About two-thirds of the beef cattle feeding in the USA occurs in Nebraska, Texas, Kansas, Iowa, and Colorado. More than $80 \%$ of the fed cattle are produced in feedlots of more than 1000 head capacity (Eghball and Power, 1994). Feeder cattle weighing 230 to $320 \mathrm{~kg}$ are normally purchased by or consigned to the feedlot operator, placed on high energy feed for 100 to $180 \mathrm{~d}$, and slaughtered at 450 to $550 \mathrm{~kg}$. Manure is normally cleaned from beef feedlots when animals are marketed or once each year. Manure collected from feedlot is somewhat stable since it has been on the feedlot surface for a long period of time. Typically, in the central and southern Great Plains, manure scraped from beef feedlots becomes mixed with as much as $50 \%$ soil and has lost about $50 \%$ of its original N content (Eghball and Power, 1994). About 26.4 million $\mathrm{Mg}$ of manure is collected annually from all feedlots in the USA. Nitrogen, P, and K in the feedlot

B. Eghball, Dep. of Agronomy, J.F. Power, J.E. Gilley, and J.W. Doran, USDA-ARS, Univ. of Nebraska, Lincoln, NE 68583. Contribution of the USDA-ARS in cooperation with the Nebraska Agric. Exp. Stn., Lincoln, NE, as paper no. 11208. Received 31 July 1995. *Corresponding author (beghball@unlinfo.unl.edu).
\end{abstract}

Published in J. Environ. Qual. 26:189-193 (1997). manure, if all collected and utilized, would have a value of \$461 million (Eghball and Power, 1994).

Composting manure is a useful method of producing a stabilized product that can be stored or spread with little odor, pathogens, weed seeds, or fly breeding potential (Sweeten, 1988). Composted manure can be applied to soil as an odorless and relatively dry source of nutrients compared with noncomposted manure. Another advantage of composting is improved handling characteristics of manure by reducing volume and weight (Willson and Hummel, 1975). Decomposition of manure occurs through biological action and spontaneous chemical reactions. The initial chemical and biological composition of manure is a function of ration fed, animal age, type of feedlot, and other factors that can influence manure production and decomposition.

In composting, $\mathrm{N}$ loss through volatilization can be a major problem. The main factors influencing gaseous $\mathrm{N}$ loss are total $\mathbf{N}$ content of material, temperature, high $\mathrm{pH}(>8)$, and turning (Martins and Dewes, 1992). In a constant temperature/humidity chamber, ammonia volatilization during composting of cattle manure resulted in a $35 \%$ decrease in ammonium- $\mathrm{N}$ content but total $\mathrm{N}$ content was not significantly changed (Stone et al., 1975). Hansen et al. (1993) reported ammonia loss during composting of poultry manure in reactor vessels to be three times greater with a $\mathrm{C} / \mathrm{N}$ ratio of 15 compared with 20 . In composting mixtures of straw and various kinds of liquid manure (swine, poultry, and cattle) in containers, between 46.8 and $77.4 \%$ of the initial $\mathrm{N}$ was lost, primarily as ammonia with a small amount $(<5 \%)$ as $\mathrm{NO}_{\mathrm{x}}$ (Martins and Dewes, 1992). Nitrogen loss during composting of a sewage sludge-straw mixture resulted primarily from ammonia volatilization (Witter and LopezReal, 1988). In the initial stages of composting, the $\mathrm{N}$ loss amounted to 16 to $29 \%$ of the initial $\mathrm{N}$ content, whereas it was $>60 \%$ when composting a limeconditioned sludge with higher initial $\mathbf{N}$ content. Compared to fresh manure, 3-mo stabilized farmyard manure had significantly greater concentrations of total N, watersoluble substances, and lignin, and less organic C, lipid, and hemicellulose, as well as a lower $\mathrm{C} / \mathrm{N}$ ratio (LeviMinzi et al., 1986).

Nitrogen can also be lost from manure in runoff and by nitrate leaching during composting. Relative quantities of $\mathrm{N}$ lost by these processes are controlled mainly by site-specific conditions. Ott et al. (1983) found high $\mathrm{K}$ loss $(28 \%)$ during composting of farmyard manure through leaching, while nitrate concentration in the leachate was low enough $\left(8 \mathrm{mg} \mathrm{NO}_{3}-\mathrm{N} \mathrm{kg}^{-1}\right)$ not to create an environmental problem. Since $\mathbf{N}$ losses are less than the reduction in volatile solids due to bio-oxidation, total $\mathrm{N}$ concentration during composting usually increases. 
Nutrient loss, specifically N, P, and K losses, reduces potential of compost as a plant nutrient source. Quantification of amount of nutrient and mass loss during composting in field conditions is important to understanding the composting process and implementing methods for conservation of nutrients to reduce potential adverse environmental impacts. Total and runoff loss of nutrient, carbon, and mass during composting of beef cattle feedlot manure has not been quantified. The objective of this study was to determine the amount of nutrient, carbon, and mass loss during composting of beef feedlot manure under field conditions.

\section{MATERIALS AND METHODS}

Beef cattle feedlot manure was composted in a windrow on a concrete area at the University of Nebraska Agricultural Research and Development Center near Mead in the summers of 1992, 1993, and 1994. Manure was collected from an unpaved feedlot with a concrete apron behind the feed bunks. Manure was composted in a windrow $3 \mathrm{~m}$ wide, $10 \mathrm{~m}$ long, and $1 \mathrm{~m}$ high each year. The compost area was enclosed on all sides with a $0.2-\mathrm{m}$ high metal sheet to drain the runoff and leachate to a fiberglass tank (4000-L capacity) through drainage pipes. The amount of runoff and leachate were measured volumetrically and a representative sample was taken for chemical analysis within $24 \mathrm{~h}$ of each rainfall. Samples were analyzed for electrical conductivity, $\mathrm{pH}$, dry matter, nitrate, ammonium, total Kjeldhal $\mathrm{N}$, soluble $\mathrm{P}$, and total $\mathrm{P}, \mathrm{K}, \mathrm{Na}, \mathrm{Mg}$, and $\mathrm{Ca}$. $A$ rain gauge was placed near the compost site to determine the amount of rainfall for each event and a sample of rain water was collected for the above chemical properties in 1992. Because nutrient concentration of rain water was not significant, we did not collect rain samples in 1993 and 1994. Dry weight of the material being composted was determined at the beginning and at the end of the process. The manure was analyzed both before and after composting for total N, C, P, K, Na, $\mathrm{Ca}, \mathrm{Mg}$, and $\mathrm{NO}_{3}-\mathrm{N}, \mathrm{NH}_{4}-\mathrm{N}, \mathrm{pH}, \mathrm{EC}$, available $\mathrm{P}$ (Bray and Kurtz no. 1), and ash content. Total amounts of mass and nutrient lost during composting were determined by the difference between the amounts at the beginning and at the end of the composting period. The amount of manure and nutrient loss by runoff was determined by measuring amounts in the water collected. Because leaching was eliminated, mass of materials collected in the tank would represent potential loss by both runoff and leaching.

A model-3 CSIRO data logger with six temperature sensors was used to determine the temperature of the composting manure at depths of $0.25,0.55$, and $0.85 \mathrm{~m}$ within the $1-\mathrm{m}$ high composting pile. The material was mixed with a front-end loader every 7 to $10 \mathrm{~d}$ or as required, based on temperature status of the composting material. Water was added to the composting windrow when the moisture level fell below $40 \%$.

\section{RESULTS AND DISCUSSION}

Nutrient contents of beef cattle feedlot manure before and after composting in 1992, 1993, and 1994 are given in Table 1. Available $P$ was about $22 \%$ of total $P$ for both composted and noncomposted manure, while combined nitrate and ammonium as a proportion of total $\mathrm{N}$ was $2.2 \%$ for noncomposted and $3.1 \%$ for composted manure.

In 1992, the manure mass loss during $110 \mathrm{~d}$ of composting was $20 \%$ of initial mass (Table 2 ). The mass loss was lower than the normal range of 35 to $50 \%$, because the feedlot manure contained a relatively large amount of soil (59\% ash) and a relatively smaller amount of carbon. A carbon source was not added to the manure, because this is not the common practice for composting beef feedlot manure as it is removed from the feedlot. Nitrogen loss during composting in 1992 was $42.5 \%$ of the initial manure $\mathrm{N}$, while $\mathrm{C}$ loss was $62 \%$ (Table 2 ). Of the total amount of $\mathrm{N}$ lost, $3.2 \%$ was removed by runoff and $96.8 \%$ was apparently volatilized. Volatilization losses were estimated by the difference between total and runoff $\mathrm{N}$ losses. Some loss of $\mathrm{N}$ as a result of denitrification during composting may also occur. However, denitrification requires the manure to be saturated, and since we kept the composting manure at 40 to $60 \%$ water content throughout the period, denitrification of $\mathrm{N}$ was probably minimal.

Phosphorus loss during composting in 1992 was $0.8 \%$ of initial manure $P$, all of which was accounted for in the runoff (Table 2). Unlike $N$, runoff loss is the main mechanism of $P$ loss during composting. Potassium and $\mathrm{Na}$ losses during composting were 15.8 and $15.5 \%$ of initial manure $\mathrm{K}$ and $\mathrm{Na}$, respectively, while $\mathrm{Ca}$ and $\mathrm{Mg}$ losses were each $<2 \%$.

In 1993, manure mass loss during composting was $14.9 \%$ (Table 2). Carbon loss was $45.9 \%$ of initial manure C, and N loss was $19.3 \%$ of initial N. Phosphorus runoff loss in 1993 was $2.2 \%$ of initial manure $P$ (Table 2). Potassium and $\mathrm{Na}$ losses during composting were 11.3 and $13.7 \%$ of initial manure $\mathrm{K}$ and $\mathrm{Na}$, respectively.

Table 1. Concentration of nutrients (on dry wt. basis) and ash, electrical conductivity (EC), and pH in the feedlot manure before and after open composting in open windrows in 3 years.

\begin{tabular}{|c|c|c|c|c|c|c|c|c|c|c|c|c|c|}
\hline Variable & $\begin{array}{c}\text { Total } \\
\mathbf{N}\end{array}$ & $\mathrm{NO}_{3}-\mathrm{N}$ & $\mathrm{NH}_{4}-\mathrm{N}$ & $\begin{array}{c}\text { Available } \\
\mathrm{P}_{\dagger}\end{array}$ & $\begin{array}{c}\text { Total } \\
\mathbf{P}\end{array}$ & $\begin{array}{c}\text { Total } \\
\mathrm{C}\end{array}$ & $\begin{array}{c}\text { Total } \\
\mathbf{K}\end{array}$ & $\begin{array}{c}\text { Total } \\
\mathrm{Na}\end{array}$ & $\begin{array}{c}\text { Total } \\
\mathrm{Ca}\end{array}$ & $\begin{array}{c}\text { Total } \\
\mathbf{M g}\end{array}$ & Ash & $\mathrm{EC} \ddagger$ & $\mathrm{pH}$ \\
\hline & & & & & & -1 & & & & & & $\mathrm{dS} \mathrm{m}^{-}$ & \\
\hline \multicolumn{14}{|l|}{1992} \\
\hline Initial manure & 15.2 & 0.03 & 0.85 & 1.53 & 6.84 & 197.7 & 11.1 & 2.0 & 10.5 & 4.5 & 587 & 12.1 & 7.4 \\
\hline Composted & 11.0 & 0.12 & 0.17 & 1.64 & 8.74 & 95.6 & 11.8 & 2.2 & 13.0 & 5.6 & 808 & 7.4 & 7.7 \\
\hline \multicolumn{14}{|l|}{1993} \\
\hline Initial manure & 8.1 & 0.00 & 0.02 & 0.63 & 3.06 & 137.4 & 11.0 & 0.7 & 6.9 & 3.8 & 700 & 3.4 & 8.9 \\
\hline Composted & 7.7 & 0.04 & 0.03 & 0.63 & 3.15 & 87.4 & 11.4 & 0.8 & 8.0 & 4.2 & 796 & 2.1 & 8.3 \\
\hline \multicolumn{14}{|l|}{1994} \\
\hline Initial manure & 9.3 & 0.03 & 0.03 & 0.79 & 3.15 & 111.4 & 8.4 & 1.1 & 12.3 & 4.6 & 770 & 1.2 & 7.6 \\
\hline Composted & 7.6 & 0.38 & 0.06 & 1.10 & 4.07 & 73.5 & 9.3 & 1.1 & 14.3 & 5.5 & 849 & 1.2 & 7.4 \\
\hline
\end{tabular}

$\uparrow$ Bray and Kurtz number one $P$ test.

$\ddagger \mathrm{EC}$ and $\mathrm{pH}$ were determined on 2:1 manure or compost to water ratio. 
Table 4. Nutrient concentration, solid, $\mathrm{pH}$, and electrical conductivity (EC) of runoff collected from composting beef feedlot manure open windrow in 1993.

\begin{tabular}{|c|c|c|c|c|c|c|c|c|c|c|c|c|c|c|}
\hline $\begin{array}{l}\text { Composting } \\
\text { days }\end{array}$ & Rain & Runoff & Solid & $\mathrm{pH}$ & EC & $\begin{array}{c}\text { Total } \\
\mathbf{N}\end{array}$ & $\mathrm{NO}_{3}-\mathrm{N}$ & $\mathrm{NH}_{4}-\mathrm{N}$ & $\begin{array}{c}\text { Soluble } \\
\mathrm{P}\end{array}$ & $\begin{array}{c}\text { Total } \\
\mathbf{P}\end{array}$ & $\begin{array}{c}\text { Total } \\
\mathbf{K}\end{array}$ & $\begin{array}{c}\text { Total } \\
\mathrm{Na}\end{array}$ & $\begin{array}{c}\text { Total } \\
\mathbf{C a}\end{array}$ & $\begin{array}{c}\text { Total } \\
\mathbf{M g}\end{array}$ \\
\hline & $\mathrm{cm}$ & $\mathbf{L}$ & $\mathrm{g} \mathrm{kg}^{-1}$ & & $\mathrm{~d} S \mathrm{~m}^{-1}$ & 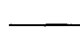 & 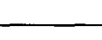 & 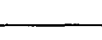 & $-\mathrm{m}$ & $\mathrm{kg}^{-1}$ & & & & \\
\hline 6 & 1.8 & 250 & 0.6 & 7.2 & 0.5 & 15 & 0.1 & 1.4 & 8.6 & 16 & 115 & 17 & 17 & 6 \\
\hline 9 & 3.0 & 930 & 1.3 & 7.1 & 0.5 & 17 & 0.2 & 25.7 & 7.8 & 17 & 116 & 15 & 17 & 5 \\
\hline 14 & 2.9 & 950 & 1.0 & 7.1 & 0.4 & 17 & 0.2 & 3.3 & 6.4 & 13 & 90 & 10 & 16 & 3 \\
\hline 18 & 1.1 & 110 & 1.0 & 7.3 & 0.6 & 19 & 0.0 & 5.2 & 11.7 & 23 & 134 & 17 & 23 & 5 \\
\hline 22 & 8.8 & 4160 & 3.4 & 7.6 & 1.8 & 77 & 0.4 & 14.7 & 9.5 & 32 & 427 & 58 & 38 & 17 \\
\hline 23 & 3.5 & 1870 & 2.5 & 7.6 & 1.8 & 67 & 0.3 & 11.0 & 11.5 & 35 & 447 & 56 & 39 & 19 \\
\hline 25 & 1.4 & 440 & 1.5 & 7.6 & 1.2 & 48 & 0.2 & 7.1 & 8.6 & 30 & 301 & 40 & 28 & 13 \\
\hline 43 & 1.1 & 340 & 4.8 & 7.3 & 0.7 & 76 & 0.1 & 7.7 & 9.6 & 27 & 174 & 19 & 23 & 8 \\
\hline 51 & 6.4 & 2370 & 1.6 & 7.6 & 0.9 & 46 & 0.2 & 14.1 & 24.0 & 42 & 182 & 26 & 38 & 13 \\
\hline 60 & 0.6 & 150 & 1.4 & 7.3 & 1.0 & 30 & 3.0 & 1.0 & 8.6 & 27 & 231 & 32 & 21 & 9 \\
\hline 64 & 3.7 & 1550 & 1.5 & 6.9 & 1.1 & 41 & 0.7 & 3.5 & 10.2 & 32 & 271 & 38 & 28 & 14 \\
\hline 82 & 3.7 & 1020 & 1.5 & 7.5 & 1.2 & 34 & 1.8 & 2.6 & 10.5 & 19 & 270 & 37 & 28 & 11 \\
\hline 85 & 1.5 & 380 & 1.0 & 7.4 & 0.6 & 22 & 1.3 & 1.3 & 6.5 & 15 & 123 & 18 & 13 & 4 \\
\hline 90 & 1.9 & 380 & 0.9 & 7.4 & 0.7 & 18 & 1.6 & 0.9 & 7.2 & 18 & 170 & 24 & 14 & 5 \\
\hline 107 & 1.7 & 250 & 0.6 & 7.5 & 0.3 & 9 & 0.9 & 0.9 & 4.4 & 9 & 55 & 11 & 14 & 3 \\
\hline
\end{tabular}

total $P$ in runoff was $23.7 \mathrm{mg} \mathrm{kg}^{-1}$ in 1993 and 17.0 in 1994 (average of all samplings). Total $P$ concentration in 1992 was even higher than in 1993 and 1994. Except for two samplings in 1992 and 1994, nitrate concentration of runoff from the compost pile was $<10 \mathrm{mg} \mathrm{kg}^{-1}$ (Tables 3,4 , and 5). In a field situation, some of this nitrate would have leached into the soil. Nienaber and Ferguson (1994) found nitrate- $\mathrm{N}$ content of $2500 \mathrm{~kg} \mathrm{ha}^{-1}$ per 7.6-m depth under a site used for composting for $9 \mathrm{yr}$. They also observed nitrate movement to a depth of $2 \mathrm{~m}$ beneath a composting site after only 2 yr of composting activity. Nitrate has a potential of reaching the groundwater if not utilized by growing plants. Ammonium concentrations of leachate were higher than $2.5 \mathrm{mg} \mathrm{kg}^{-1}$ level at all sampling times in 1992 and 1994 and in most sampling times in 1993 (Tables 3, 4, and 5). Ammonium$\mathrm{N}$ concentrations $>2.5 \mathrm{mg} \mathrm{kg}^{-1}$ may be harmful to fish (USEPA, 1973). Potassium and $\mathrm{Na}$ concentrations in runoff were also high and may have adverse effects on soil structure.

Temperature reached $65^{\circ} \mathrm{C}\left(149^{\circ} \mathrm{F}\right)$ within $24 \mathrm{~h}$ of starting the composting process at all depths within the compost pile in 1992 (Fig. 1). A temperature of $55^{\circ} \mathrm{C}$ for $3 \mathrm{~d}$ is necessary to destroy the pathogens in the compost while critical temperature for killing most weed seeds is $63^{\circ} \mathrm{C}$ (Rynk et al., 1992). Temperature was consistently lower at all compost depths in 1993 than in 1992 and reached $55^{\circ} \mathrm{C}$ only for a short period at the 55-cm depth within the compost. The difference is probably due to lower manure $\mathrm{C}$ and $\mathrm{N}$ concentrations in 1993 than in 1992 (Table 1). Significant drops in temperature indicate the times when the windrow was turned. Around Day 65 , the temperature decreased to $40^{\circ} \mathrm{C}\left(104^{\circ} \mathrm{F}\right)$, indicating the end of the thermophilic process in both years. After this, the windrow was no longer turned, and the material was allowed to cure for an additional $45 \mathrm{~d}$. After this period, the temperature of the composted material was near ambient. In 1994, because of technical difficulties, we were unable to determine temperature for the entire composting period. However, manure temperature reached $65^{\circ} \mathrm{C}$ after $2.5 \mathrm{~d}$ of composting at the 85- and $25-\mathrm{cm}$ depths within the composting pile (data not shown). About $110 \mathrm{~d}$ was necessary for completion of the composting process each year.

\section{CONCLUSIONS}

Nutrient loss, specifically $\mathrm{N}$, can be a major problem in composting of feedlot manure. As much as $40 \%$ of total manure $\mathrm{N}$ can be lost during composting. Nitrogen loss during composting was related to total $\mathrm{N}$ content of manure. The $\mathrm{C} / \mathrm{N}$ ratio of manure had a smaller effect on $\mathrm{N}$ loss. Losses of $\mathrm{K}$ and $\mathrm{Na}$ in runoff and leachate from the composting manure can also be substantial in years with large numbers of rainfall events. Phosphorus loss during composting was small and resulted mainly through runoff. Reduced electrical conductivity after composting in 1992 and 1993 indicated that loss of nutrients reduced salt content of the manure. Temperature necessary to destroy pathogens and weed seeds were generated within the compost in 1992 and 1994. These temperatures were not routinely obtained in 1993 because of the low $\mathrm{C}$ and $\mathrm{N}$ content of manure being composted. Runoff and leaching from composting sites may be a significant contributor of $\mathrm{N}, \mathrm{P}, \mathrm{K}$, and $\mathrm{Na}$ to surface and ground waters. Because of $\mathrm{N}, \mathrm{K}, \mathrm{Na}$, and $\mathrm{C}$ loss

Table 5. Nutrient concentration, solid, $\mathrm{pH}$, and electrical conductivity (EC) of runoff collected from composting beef feedlot manure open windrow in 1994.

\begin{tabular}{|c|c|c|c|c|c|c|c|c|c|c|c|c|c|c|}
\hline $\begin{array}{l}\text { Composting } \\
\text { days }\end{array}$ & Rain & Runoff & Solid & $\mathrm{pH}$ & EC & $\underset{\mathrm{N}}{\text { Total }}$ & $\mathrm{NO}_{3}-\mathrm{N}$ & $\mathrm{NH}_{4}-\mathrm{N}$ & $\begin{array}{l}\text { Soluble } \\
\mathbf{P}\end{array}$ & $\begin{array}{c}\text { Total } \\
\mathbf{P}\end{array}$ & $\begin{array}{c}\text { Total } \\
\mathbf{K}\end{array}$ & $\begin{array}{c}\text { Total } \\
\mathrm{Na}\end{array}$ & $\begin{array}{c}\text { Total } \\
\text { Ca }\end{array}$ & $\begin{array}{c}\text { Total } \\
\mathbf{M g}\end{array}$ \\
\hline & $\mathrm{cm}$ & $\mathbf{L}$ & $\mathrm{g} \mathrm{kg}^{-1}$ & & $\mathrm{dS} \mathrm{m}^{-1}$ & & & 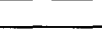 & $-\mathbf{m}$ & $\mathrm{kg}^{-1}$ & & & & \\
\hline 5 & 2.1 & 265 & 2.4 & 6.8 & 0.9 & 25 & 0.3 & 7.0 & 10.8 & 15 & 151 & 52 & 42 & 14 \\
\hline 29 & 1.3 & 265 & 7.0 & 7.3 & 1.5 & 114 & 0.3 & 19.6 & 10.9 & 22 & 268 & 81 & 47 & 20 \\
\hline 44 & 2.5 & 475 & 1.6 & 6.9 & 1.1 & 35 & 8.7 & 11.0 & 8.9 & 11 & 219 & 56 & 23 & 12 \\
\hline 55 & 3.8 & 1230 & 3.7 & 7.1 & 0.9 & 72 & 8.6 & 19.2 & 12.6 & 23 & 253 & 65 & 23 & 16 \\
\hline 72 & 5.8 & 1225 & 1.6 & 7.0 & 0.7 & 30 & 25.1 & 5.0 & 12.1 & 14 & 212 & 58 & 27 & 16 \\
\hline
\end{tabular}




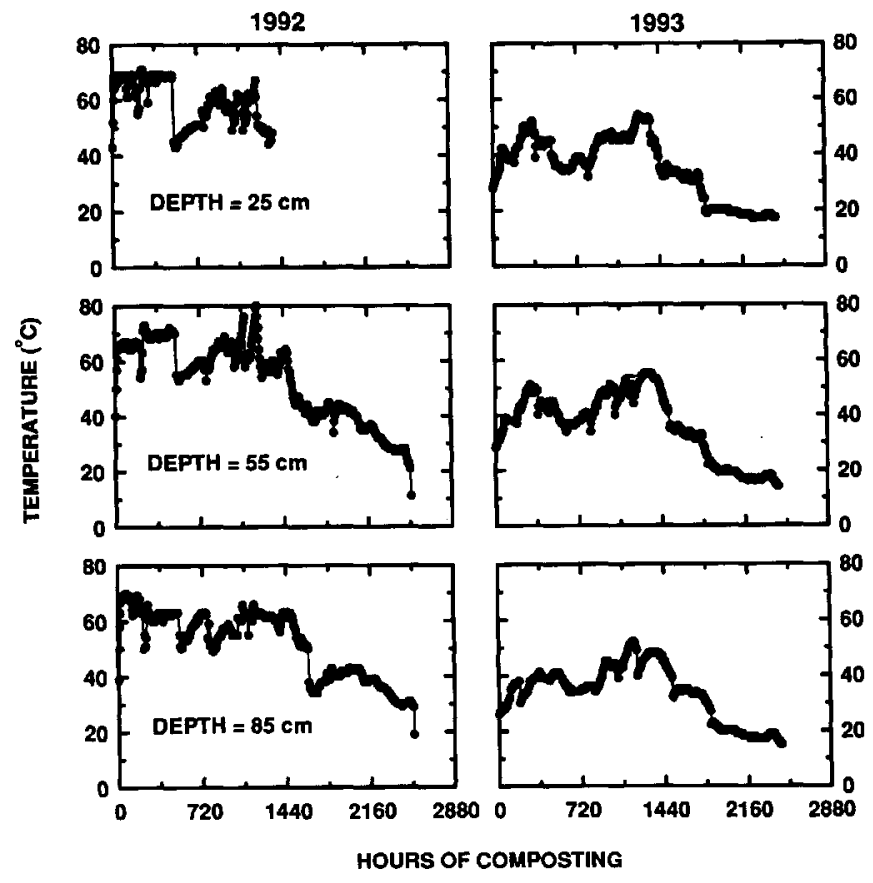

Fig. 1. Temperature of the feedlot manure composting windrows at three depths in 2 yr at Mead, NE.

during composting, beef feedlot manure should be applied to the land without composting unless weed seeds, better handling of manure, odor, or others are of concern.

\section{REFERENCES}

Eghball, B., and J.F. Power. 1994. Beef cattle feedlot manure management. J. Soil Water Conserv. 49:113-122.

Hansen, R.C., H.M. Keener, C. Marugg, W.A. Dick, and H.A.J. Hoitink. 1993. Composting of poultry manure. p. 131-153. In H.A.J. Hoitink and H.M. Keener (ed.) Science and engineering of composting: Design, environmental, microbiological and utilization aspects. Renaisssance Publ., Worthington, $\mathrm{OH}$.

Levi-Minzi, R., R. Riffaldi, and A. Saviozzi. 1986. Organic matter and nutrients in fresh and mature farmyard manure. Agric. Wastes $16: 225-236$.

Martins, O., and T. Dewes. 1992. Loss of nitrogenous compounds during composting of animal wastes. Bioresource Technol. 42: 103-111.

Nienaber, J.A., and R.B. Ferguson. 1994. Nitrate concentration in the soil profile beneath compost areas. p. 233-237. In D.E. Storm and K.G. Casey (ed.) Proc. of the Great Plains Animal Wastes Conf. on Confined Animal Production and Water Quality, Denver, CO. 19-21 Oct. 1994. National Cattlemen's Assoc., Englewood, $\mathrm{CO}$.

Ott, P., S. Hansen, and $H$. Vogtmann. 1983. Nitrates in relation to composting and use of farmyard manures. p. 145-154. In Environmentally sound agriculture. 4th Conf. Int. Federation of Organic Agric. Movements, Proeger, NY.

Rynk, R., M. van de Kamp, G.B. Willson, M.E. Singley, T.L. Richard, J.J. Kolega, F.R. Gouin, L. Laliberty, Jr., D. Kay, D.W. Murphy, H.A.J. Hoitink, and W.F. Brinton. 1992. On farm composting. Northeast Regional Agric. Eng. Service, Ithaca, NY.

Smith S.J., A.N. Sharpley, W.A. Berg, J.W. Naney, and G.A. Coleman. 1992. Water quality characteristics associated with Southern Plains grasslands. J. Environ. Qual. 21:595-601.

Stone, M.L., J.M. Harper, and R.W. Hansen. 1975. Decomposition rates of beef cattle wastes. Managing livestock wastes. p. 344346. In Proc. 3rd Int. Symp. on Livestock Wastes, UrbanaChampaign, IL. 21-24 Apr. 1975. ASAE, St. Joseph, MI.

Sweeten, J.M. 1988. Composting manure and sludge. p. 38-44. In National Poultry Waste Management Symp., Columbus, OH. 1819 Apr. 1988. Dep. of Poultry Science, Ohio State Univ., Colum. bus, $\mathrm{OH}$

U.S. Department of Agriculture. 1993. Agricultural statistics 1993. U.S. Gov. Print. Office, Washington, DC.

U.S. Environmental Protection Agency. 1973. Water quality criteria. U.S. Gov. Print. Office, Washington, DC.

Willson, G.B., and J.W. Hummel. 1975. Conservation of nitrogen in dairy manure during composting. p. 490-496. In Managing livestock wastes. Proc. 3rd Int. Symp. on Livestock Wastes, Urbana-Champaign IL. 21-24 Apr. 1975. ASAE, St. Joseph, MI.

Witter, E., and J. Lopez-Real. 1988. Nitrogen losses during the composting of sewage sludge, and the effectiveness of clay soil, and compost in adsorbing the volatilized ammonia. Biol. Wastes 23:279-294. 